\title{
The Effects of Impulse Noise on the Epithelial Cells of the Choroid Plexus
}

\author{
Ses Impulslarmın Koroid Pleksus Epitel Hücreleri Üzerine Etkisi
}

\author{
Mehmet Dumlu AYDIN ${ }^{2}$, Mehmet Kaan UNGOREN ${ }^{1}$, Nazan AYDIN ${ }^{3}$, Zekai HALICI ${ }^{4}$, Arif ONDER 5 , \\ Cemal GUNDOGDU ${ }^{6}$, Yusuf IZCI ${ }^{7}$
}

${ }_{1}^{1}$ M.H. Luleburgaz State Hospital, Department of Neurosurgery, Kirklareli / Luleburgaz, Turkey

${ }^{2}$ Ataturk University, Faculty of Medicine, Department of Neurosurgery, Erzurum, Turkey

${ }^{3}$ Ataturk University, Faculty of Medicine, Department of Psychiatry, Erzurum, Turkey

${ }^{4}$ Ataturk University, Faculty of Medicine, Department of Pharmacology, Erzurum, Turkey

519 Mayzs University, Faculty of Medicine, Department of Neurosurgery, Samsun, Turkey

${ }^{6}$ Ataturk University, Faculty of Medicine, Department of Pathology, Erzurum, Turkey

${ }^{7}$ Gulhane Military Medical Academy, Department of Neurosurgery, Ankara, Turkey

Correspondence address: Mehmet Kaan UNGOREN / E-mail: kungoren@gmail.com

\begin{abstract}
AIM:The aim of this study was to investigate the effects of impulse noise on the epithelial cells of the choroid plexus.

MATERIAL and METHODS: Forty Sprague Dawley rats were used and divided into the 2 groups as control and study groups. In the control group, the rats did not suffer noise injury. The rats were exposed to impulse noise at 20 minute durations at 10 times each day for one month in study group. Then, the rats were sacrificed and the choroid plexuses were examined histologically. The number of cells was counted and the cells were analyzed.
\end{abstract}

RESULTS: There were clear signs of nuclear condensation and cell body shrinkage, suggesting the presence of apoptosis. Severe desquamation of villus and the cell loss were observed in the study group. The numbers of the normal cells decreased, and the number of apoptotic cells increased significantly $(\mathrm{p}<0.05)$.

CONCLUSION: Impulse noise causes apoptotic death of epithelial cells in the choroid plexus, decrease the normal cells and increase the apoptotic cells.

KEYWORDS: Impulse noise, Choroid plexus, Apoptosis

öz

AMAÇ: Bu çalışmanın amacı, gürültünün koroid pleksus epitel hücreleri üzerine olan etkilerini araştırmaktır.

YÖNTEM ve GEREÇ: Bu çalışmada, kırk adet Sprague Dawley sıçanı kullanıldı ve çalışma ve de kontrol grubu olarak ikiye ayrıldı. Kontrol grubundaki sıçanlara ses impulsları uygulanmadı. Diğer yandan çalışma grubundaki sıçanlar bir ay boyunca, her gün, on kez, 20 dakika süreyle gürültüye maruz bırakıldı. Daha sonra, sıçanlar kesildi ve koroid pleksusları histolojik olarak çalışıldı. Hücre sayıları hesaplandı ve analiz edildi.

BULGULAR: Apoptozisin varlığını kanıtlayan çekirdek yoğunlaşması ve hücre cisminde küçülmeye dair açık bulgular vardır. Çalışma grubunda, villuslarda ciddi deskuamasyon ve hücre kaybı gözlendi. Normal hücre sayıları azaldı ve apoptotik hücre sayıları dikkate değer ölçüde arttı.

SONUÇ: Gürültü apoptotik hücrelerde artışa, normal hücre sayılarında azalmaya, koroid pleksus epitel hücrelerinde apoptotik ölüme neden olur.

ANAHTAR SÖZCÜKLER: Gürültü, Koroid pleksus, Apoptozis

\section{INTRODUCTION}

Vibroacoustic disease is an insidious and serious environmental entity caused by occupational exposure to large pressure amplitude $(>90 \mathrm{~dB})$ and low frequency $(<500$ $\mathrm{Hz})$ noise. Impulse noise cause significant disabilities such as neurological (34\%), malignant (11.9\%), psychiatric (9.7\%), cardiovascular (6.8\%), and osteoarticular (5.9\%) changes and suicide attempts (1). Exposure to intense impulse noise $(202 \mathrm{~dB} / 2 \mathrm{~h})$ may cause diffuse prominent neuronal injury, apoptosis, and gliosis in the hippocampus and cerebral cortex and cochlea (18). It was also identified that impulse noise can cause antibody generation against to microglial cells and astrocytes in the cerebral cortex, the dentate gyrus and in the pyramidal cell layers and white matter of the hippocampus (15). 
Choroid plexuses are located in the ventricles and comprised of highly vascularised villi covered by a ciliated modified ependyma epithelium (2). They are highly vulnerable to damage in head injuries (11), infections (21) and ischemic conditions (13).

Exposure to intense impulse noise ( $202 \mathrm{~dB} / 2 \mathrm{~h}$ ) may cause diffuse brain injury, revealed by increased expression of immediate early gene products, transiently altered distribution of neurofilaments, accumulation of beta-amyloid precursor protein (beta-APP), apoptosis, and gliosis (18). Although exposure to impulse noise may cause diffuse brain injury, the effects of impulse noise on the choroid plexus (CP) cells has not been well known.

The goal of the present study was to investigate if an exposure to impulse noise affected the epithelial cells of the choroid plexus. Two different methods, histological examination and the number of apoptotic cells, were used as indicators of cell damage.

\section{MATERIAL and METHODS}

This study was performed on 40 adult Sprague Dawley rats. Ten rats ( 5 male and 5 female) were in the control group and 30 rats ( 15 male and 15 female rats) in the study group. The rats weighed $300 \mathrm{~g} \pm 25 \mathrm{~g}$. Experiments were carried according to the guidelines set by the ethical committee of our faculty. They were followed up for one month in their personal cages in a room which had a standard day-night cycle. Disco music was listened to by all animals at 20 minute durations 10 times each day for one month.

Noise presentation was performed by a high fidelity sound system composed of a Pioneer PD-310 CD player, Yamaha P4500 amplifier, and loudspeaker. A loudspeaker was placed in front of each animal cage so that both ears of all animals were affected by the noise at the same intensity while the distance between the loudspeaker and the cages was 100 $\mathrm{cm}$. The physical characteristics of the music sounds were as follows: an AZ instrument Corp. Sound level meter (model 8926) with frequency range from $300 \mathrm{~Hz}$ to $8 \mathrm{KHz}$ and $\pm 2 \mathrm{~dB}$ sensitivity was used to determine the intensity of the music signal and it was measured as $120 \mathrm{~dB}$. Sound waves and their physical characteristics are shown in Figure 1. A LeyboldHeraeus crystal microphone with high impedance, frequency range $50 \mathrm{~Hz}$ to $15 \mathrm{kHz}$, which was particularly suitable for experiments with the directional sound receiver and for receiving speech and music was used. A feedback model OS-904OD oscilloscope at $40 \mathrm{MHz}$ was used for determining the period of the music signal frequency. The period $(T)$ of unknown signal was measured simply and the frequency (f) was calculated using the formula: $f=1 / T$. The period of the music signal with $120 \mathrm{~dB}$ intensity was measured as $0.4 \mathrm{~ms}$ and the frequency was $2500 \mathrm{~Hz}$.

At the end of the experiment, all the rats were anesthetized using diethyl ether, were beheaded and the brains were removed rapidly. All the brains were cut at the level of lateral ventricle body and the choroid plexuses were removed from

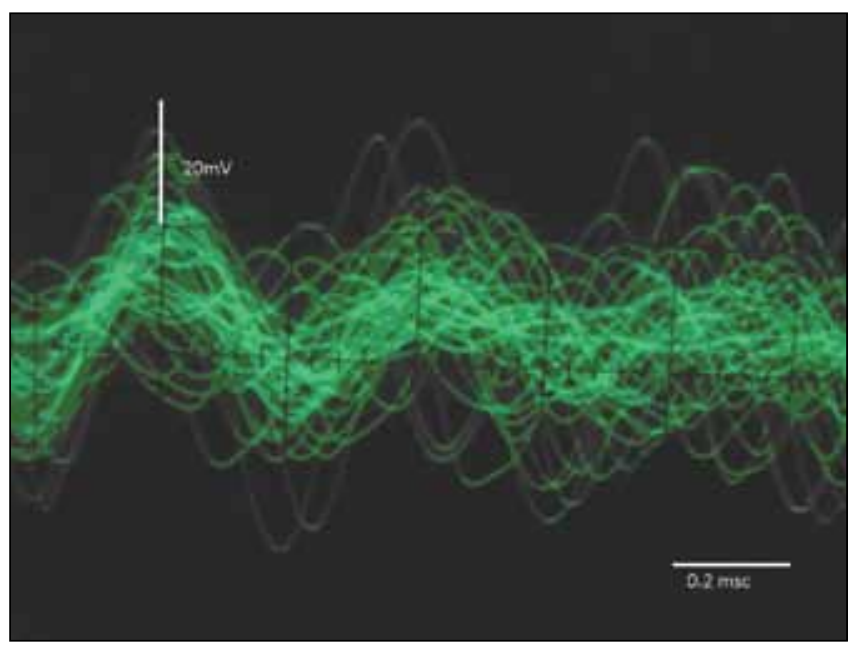

Figure 1: The period of the music signal with $120 \mathrm{~dB}$ intensity was measured as 0,2 ms and frequency was calculated as $2500 \mathrm{~Hz}$. Horizontal boundaries of all squares at the background of sound waves are equal to 0.2 milliseconds ( $\mathrm{msc}$ ) and vertical boundaries are equal to 20 millivolts $(\mathrm{mV})$. The energy level of using sound waves were measured as $120 \pm 5$ decibels (dB).

the lateral ventricles. The choroid plexuses were embedded in paraffin blocks after being kept in $10 \%$ formaline solution for 7 days.

Five- $\mu \mathrm{m}$ tissue sections were prepared and hematoxylin and eosin (H\&E) and terminal deoxynucleotidyl transferasemediated 20-deoxyuridine 50-triphosphate-biotin nick end labeling (TUNEL) staining were used to detect cell death in the choroid plexus.

The physical dissector method was used to evaluate the numbers of cells in the choroid plexus. This method can easily estimate the particle number, can be readily performed, is intuitively simple, is free from assumptions about particle shape, size and orientation, and is unaffected by overprotection and truncation. Data were obtained from the dissector pairs consisting of parallel sections taken at known intervals until the tissue samples became exhausted. Two consecutive sections mounted on each slide were named as reference base. Twenty dissector pairs were taken in each block for the analysis of cells.

A counting frame was placed on consecutive section photographs on screen of PC for counting of cells in each specimen according to the dissector method. Cells of choroid plexus regions were counted if they were visible in the reference section.

Reference and look-up sections were reversed in order to double the number of dissector pairs without taking new sections. The mean numerical density of normal (Nc) and degenerated neurons (Dc) in the CP per $\mathrm{mm} 3$ was estimated using the following formula.

$\boldsymbol{N} \boldsymbol{c}$ or $\boldsymbol{D} \boldsymbol{c}=\boldsymbol{\Sigma} \boldsymbol{Q}^{\prime} \boldsymbol{N} / \boldsymbol{\Sigma} \boldsymbol{A} \times \boldsymbol{d}$ where $\boldsymbol{\Sigma} \boldsymbol{Q}^{\prime} \boldsymbol{N}$ is the total number of counted cells of the choroid plexus appearing only in the 
reference sections; $\mathbf{d}$ is the section thickness, and $\mathbf{A}$ is the area of the counting frame. The most effective way of estimating $\boldsymbol{\Sigma} \mathbf{A}$ for the set of dissectors is via $\boldsymbol{\Sigma} \boldsymbol{A}=\boldsymbol{\Sigma} \boldsymbol{P} \times \boldsymbol{a} . \boldsymbol{\Sigma} \boldsymbol{P}$ is the total number of counting set frames points and $\mathbf{a}$ is a constant area associated set point. $A$ and $B$ are the areas of the counting frames (Figure 2A, B). The Cavalieri volume estimation method was used to obtain the total number of cells in each specimen. The total number of cells was calculated by multiplication of the volume ( $\mathrm{mm} 3)$ and the numerical density of cells in each CP. Normal and degenerated cell numbers in the choroid plexus regions of rats were compared statistically.

For the statistical analysis between the apoptotic and normal cell numbers of choroid plexus, the cell numbers were detected by the Cavalieri and Stereological methods.

\section{RESULTS}

During the noise presentation, the animals were observed through a small window. At the beginning, they showed agitation and defensive reactions. In time, some animals adapted to noise but some of them continued tp have maladaptive reactions. Weight loss, hair loss, cutaneous injury, self-biting and vulnerable attacks to each other were observed.

Horizontal boundaries of all squares at the background of sound waves are equal to 0.2 milliseconds (msc) and vertical boundaries are equal to 20 millivolts $(\mathrm{mV})$. The energy level of using sound waves was measured as $120 \pm 5$ decibels (dB). All the physical characteristics of using sound waves and their physical parameters are shown in Figure 1. The mean cell density of the choroid plexus was estimated as $43.000 \pm$ 7500 per mm3 by using stereological methods (Figure 2A, B). Choroid plexus villi contained large capillaries surrounded by a thin stroma and were covered by a cuboidal epithelium with brush borders. Epithelial cells of the choroid plexus in control rats showed round, centrally located nuclei. The mean height of normal epithelial cells were $13.65 \pm 3.20 \mu \mathrm{m}$, and that of apical microvilli $2.90 \pm 0.65 \mu \mathrm{m}$ (Figure 3). In the study group, the mean height of normal epithelial cells were 9.45 $\pm 1.40 \mu \mathrm{m}$, and that of apical microvilli $1.20 \pm 0.75 \mu \mathrm{m}$. In the study group, epithelial cells were flattened, with an irregular elongated nucleus, cytoplasmic condensations, cellular shrinkage and angulations were observed.

There were clear signs of nuclear condensation and cell body shrinkage, suggesting the presence of epithelial cells apoptosis (Figure 4). Apoptotic cells were further detected by positive staining of the TUNEL assay.

A substantial number of cells were damaged in the choroid plexus following impulse noise exposure at $120 \mathrm{~dB}$ for a period of one month. There were severe desquamation of villi and epithelial cell loss in the impulse noise exposed group. Dark TUNEL positive cells in the choroid plexus were abundantly observed in the study group (Figure 5).

Moreover, the cell density of choroid plexus was estimated as $43.000 \pm 7500$ per $\mathrm{mm} 3$. The normal cell density was significantly reduced and the apoptotic cell density was
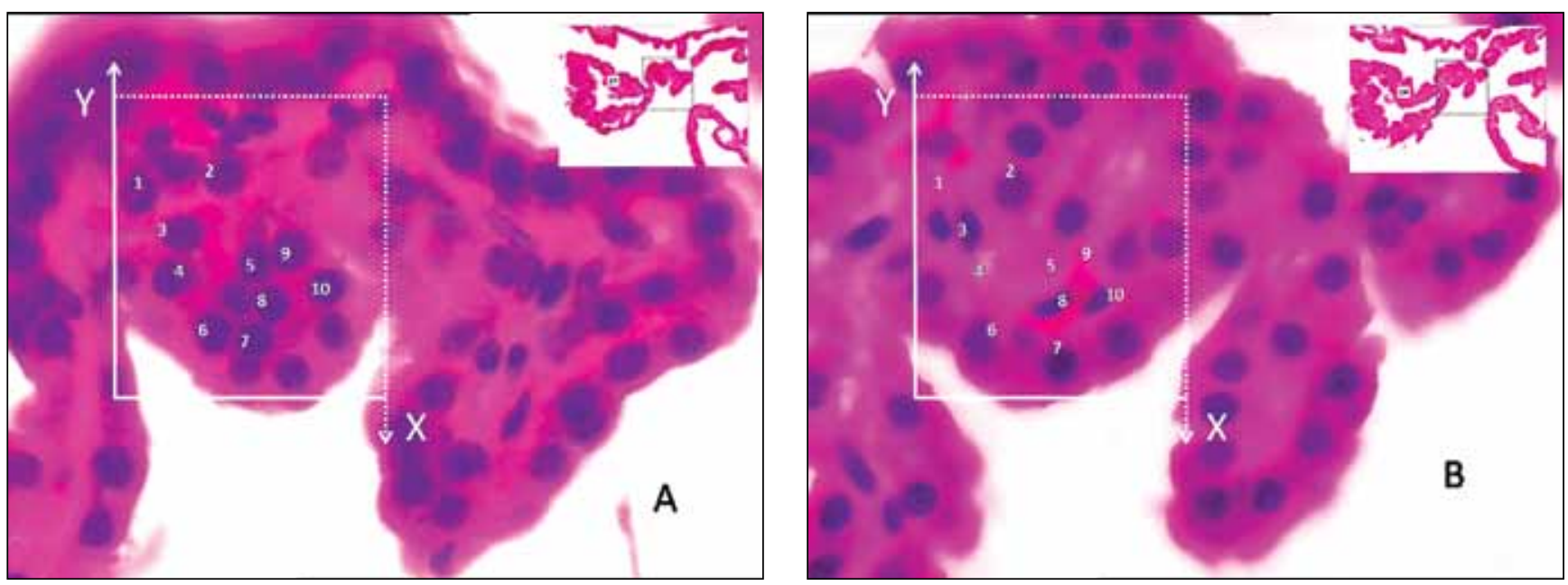

Figure 2A,B: Stereological histopathological demonstration of CP in reference sections. Stereological cell counting method of CP is seen in two parallel adjacent sections. Application of the physical dissector method in which micrographs in same fields of view (A,B) are taken from two parallel adjacent thin sections separated by a distance of $5 \mu \mathrm{m}$. Upper and right lines of unbiased counting frames represent the inclusion lines and the lower and left lines including the extensions are exclusion lines. Any neuron nucleolus on the inclusion lines is excluded and nucleolus profiles hitting the inclusion lines and located in side the frame are counted as dissector particles unless their profile extends up to the look-up section. The number of neurons from the two dissectors occurs in a volume given by the product of the counting frame are distance between the sections. The numerical density of normal (Nc) and/or degenerated neurons (Dc) is calculated from $\mathrm{Nc}$ or $\mathrm{Dc}=\Sigma \mathrm{Q}^{\prime} \mathrm{N} / \Sigma \mathrm{A} \times \mathrm{d}$. In this application, the nucleoli of normal neurons marked with 1, 4, 5, and 9 are dissector particles on section $A$ as they disappeared on section $B$, and those marked with 2, 3, 6-8, and 10 are not dissector particles. The nucleoli that appear in both sections were not accepted as dissector particles (LM, H\&E, x40). 
increased significantly in the choroid plexus after the exposure of the impulse noise $(p<0.05)$.

Apoptotic and normal cell density in the choroid plexus of each group is shown in Table $\mathrm{I}$.

\section{DISCUSSION}

The effect of impulse noise on the choroid plexus cells of the rats was investigated. It was shown that noise has a destructive effect on the epithelial cells of the choroid plexus and causes apoptosis, desquamation of the villus and hair cell loss.

Exposure to impulse noise, above a certain level, is harmful to auditory and nervous system. Effects of impulse noise on the central nervous system (CNS) are largely undiscovered, and there is little information on the critical intensity threshold level.

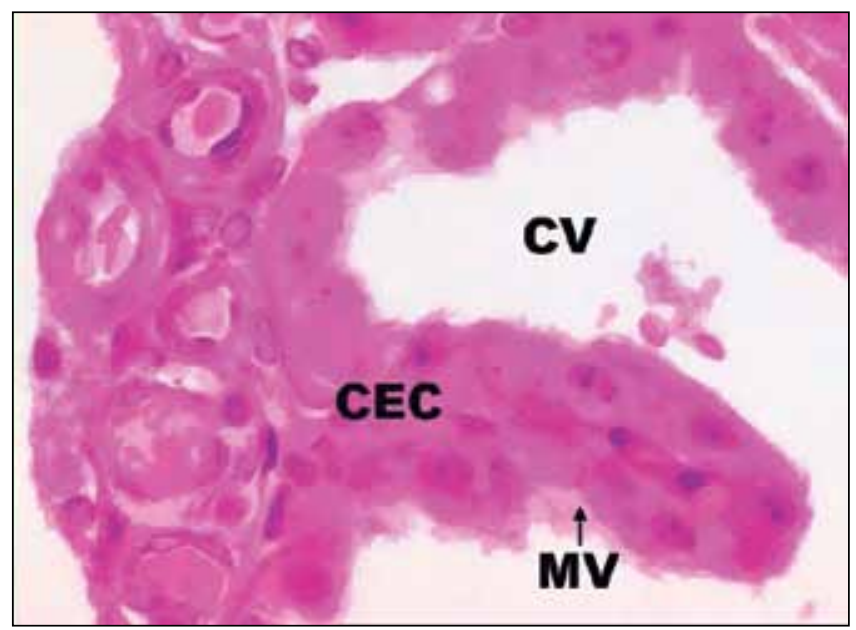

Figure 3: Histological examination of the choroid plexus in a normal rat (CV: Cerebral ventricle, CEC: Columnar epithelial cells, MV: Microvillus). (LM, H\&E, x100).

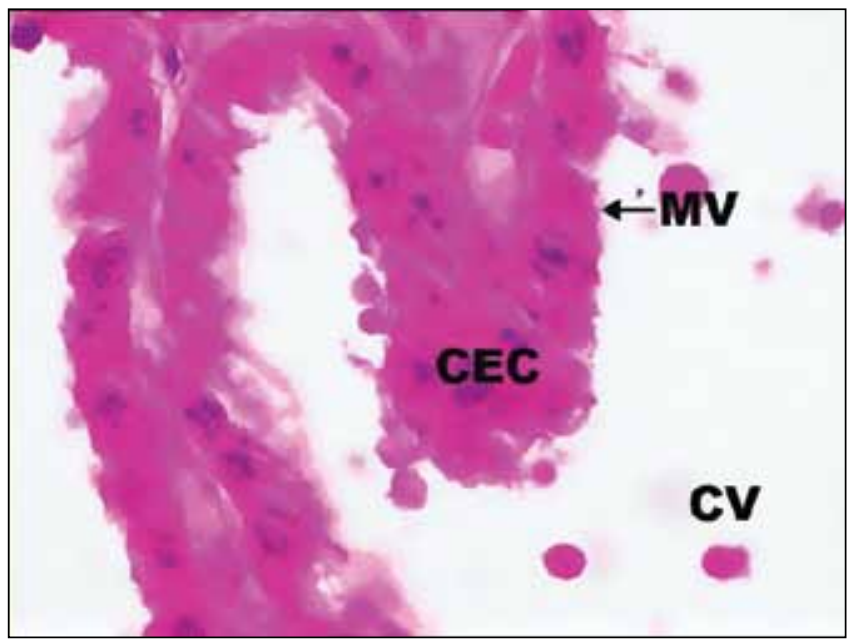

Figure 4: Microvillus atrophy and cellular degeneration are prominent in study group (CV: Cerebral ventricle, CEC: Columnar epithelial cells, MV: Microvillus). (LM, H\&E, x100).
Impulse noise affects neurofilament proteins in the cerebral cortex and the hippocampus. Granule neurons of the dentate gyrus and the CA1-3 in the hippocampus pyramidal neurons were similarly affected (16). Abnormal deposition of betaAPP was evident within $6 \mathrm{~h}$ in the same brain regions. The beta-APP immunoreactivity was most prominent at $18 \mathrm{~h}$ and remained increased over the 21-day period assessed. The observed effects were similar to those described in humans following traumatic brain injury and in Alzheimer's disease $(17,19)$. Microglial cells with an antibody against the complement receptor type 3 (OX - 42) and astrocytes with an antibody against the glial fibrillary acidic protein (GFAP) were identified following exposure to impulse noise. Astrogliosis was observed in the cerebral cortex, the dentate gyrus and in the pyramidal cell layers as well as in the white matter of the hippocampus (15).

Exposure to the noise during pregnancy caused growth retardation, decreased neurogenesis in the hippocampus, and impaired spatial learning ability in pups. On the other hand, exposure to music during pregnancy caused increased neurogenesis in the hippocampus and enhanced spatial learning ability in pups (6). Although exposure to impulse noise may cause diffuse brain injury, the effects of impulse noise on the choroid plexus (CP) cells is not well known. In our study, we found that impulse noise has destructive effects on the epithelial cells of the choroid plexus.

The choroid plexuses are brain structures located in the brain ventricles, comprised of highly vascularised villi and ciliated modified ependyma (2). It is well known that CP have important roles in cerebral nutrition, detoxification, enhancement of cerebral immunity with its immunoglobulin production, maintenance of endocrine, secretory, repository functions and regulation of blood-cerebrospinal fluid (CSF) $\mathrm{pH}$ (20). The choroid plexuses are involved in the production of cerebrospinal fluid (CSF) and in the synthesis

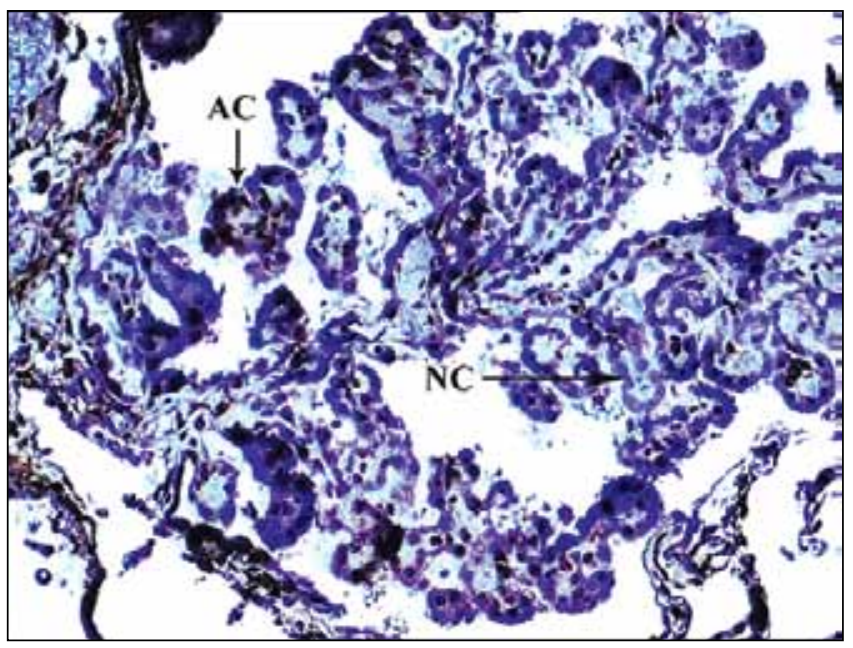

Figure 5: TUNEL Stain in the study group. Normal cells are stained in blue and apoptotic cells are stained in brown (LM, Tunel Stain, x40). (AC: Apoptotic cell, NC: Normal cell). 
Table I: The Cell Density in Control and Study Groups

\begin{tabular}{l|c|c} 
Groups & Normal cell density $\left(\right.$ cell $\left./ \mathrm{mm}^{3}\right)$ & Apoptotic cell density $\left(\mathrm{cell} / \mathrm{mm}^{3}\right)$ \\
\hline Control Group & $43.000 \pm 7500$ & $50 \pm 15$ \\
\hline Study Group & $22.000 \pm 5760$ & $17.600 \pm 4500$
\end{tabular}

and transport of numerous CSF components (20). Choroid plexuses constitute a selective CSF-blood barrier, participate in cerebral immune surveillance (10) and various enzymatic activities (9). Epithelial cells of the choroid plexus provide concentrative transport towards the CSF for hormones such as prolactin (7), and some vitamins as thiamine, vitamins $C$ and B12 or folates (20). The destruction of the epithelial cells possibly disturbs the transport of the hormones and vitamins towards the CSF, the immunity of the brain and the CSF-blood barrier. The effects of intense impulse noise on the choroid plexus have however not been studied yet.

We showed that impulse noise damages the microvilli and epithelial cells of the choroid plexus. This may cause disruption of choroid plexus functions.

Apoptosis is an active death process, requiring an adequate energy supply to fuel the apoptotic machinery at the early phase of death process. Intracellular energy level plays a pivotal role in determining whether a cell degenerates by the process of apoptosis or necrosis (8). Apoptotic degeneration of the choroid plexus can be determined by TUNEL staining (3). Many different types of hairy cell damage were observed in noise-exposed cochleae and the changes found in the inner and outer hairy cells were found to differ considerably (14).

Single impulse noise exposure (194 kPa) is known to induce apoptotic cell death signaling in the cochlear ciliary cells after 3 or $24 \mathrm{~h}$ (12). Apoptotic death of hair cells in the cochlea has been found following exposure to intense noise at $155 \mathrm{~dB}$. These results suggest the presence of a delayed mitochondrial dysfunction in apoptotic hair cells following exposure to intense noise (4). It is also demonstrated that induction of outer hair cell apoptosis after the noise exposure is an extremely rapid process (5). In our study, the number of apoptotic cells was increased significantly in the impulse noise exposed rats and the number of normal cell was decreased in choroid plexus. We do not know whether this process is rapid or not. We thought that a similar mechanism of apoptotic degeneration in the cochlea may be responsible for the degeneration of the choroid plexus cells.

\section{CONCLUSION}

The exposure to the impulse noise causes severe damage to the microvillus and epithelial cells of choroid plexus. Further studies are needed to explore the possible effects of this damage on the CSF functions.

\section{REFERENCES}

1. Castelo Branco NA, Rodriguez E, Alves-Pereira M, Jones DR: Vibroacoustic disease: Some forensic aspects. Aviat Space Environ Med 70: 145-151, 1999

2. Dohrmann GJ: Choroid plexus: A historical review. Brain Res 18: 197-218, 1970

3. Ferrand-Drake MF: Cell death in the choroid plexus following transient forebrain global ischemia in the rat. Microsc Res Tech 52: 130-136, 2001

4. $\mathrm{Hu}$ BH: Delayed mitochondrial dysfunction in apoptotic hair cells in chinchilla cochleae following exposure to impulse noise. Apoptosis 12: 1025-1036, 2007

5. $\mathrm{Hu} \mathrm{BH}$, Henderson D, Nicotera TM: Extremely rapid induction of outer hair cell apoptosis in the chinchilla cochlea following exposure to impulse noise. Hear Res 211: 16-25, 2006

6. Kim H, Lee MH, Chang HK, Lee TH, Lee HH, Shin MC, Shin MS, Won R, Shin HS, Kim CJ: Influence of prenatal noise and music on the spatial memory and neurogenesis in the hippocampus of developing rats. Brain Dev 28: 109-114, 2006

7. Kvitnitskaya-Ryzhova T, Shinkai T, Ooka H, Ohtsubo K: Immunocytochemical demonstration of prolactin interaction with choroid plexus in aging and acute hyperprolactinemia. Mech Aging Dev 76: 65-72, 1994

8. Majno G, Joris I: Apoptosis, oncosis and necrosis. An overview of cell death. Am J Pathol 146: 3-15, 1995

9. Masuzawa $\mathrm{T}$, Sato $\mathrm{H}$ : The enzyme histochemistry of choroid plexus. Brain 106: 55-99, 1982

10. Matyszak MK, Lawson LJ, Perry VH, Gordon S: Stromalmacrophages of the choroid plexus situated at the interface between the brain and peripheral immune system constitutively express major histocompatibility class II antigens. J Neuroimmunol 40: 173-181, 1992

11. Maxwell WL, Hardy IG, Watt C, McGadey J, Graham DI, Adams $\mathrm{JH}$, Gennarelli TA: Changes in the choroid plexus, responses by intrinsic epiplexus cells and recruitment from monocytes after experimental head acceleration injury in the non-human primate. Acta Neuropathol 84: 78-84, 1992

12. Murai N, Kirkegaard M, Jaerlebark L, Risling M, Suneson A, Ulfendahl M: Activation of JNK in the inner ear following impulse noise exposure. J Neurotrauma 25: 72-77, 2008

13. Nagahiro S, Goto S, Korematsu K, Sumi M, Takahashi M, Ushio Y: Disruption the blood-cerebrospinal fluid barrier by transient cerebral ischemia. Brain Res 633: 305-311, 1994

14. Rydmarker $S$, Nilsson P: Effects on the inner and outer hair cells. Acta Otolaryngol Suppl 441: 25-43, 1987

15. Saljo A, Bao F, Hamberger A, Haglid KG, Hansson HA: Exposure to short-lasting impulse noise causes microglial and astroglial cell activation in the adult rat brain. Pathophysiology 8: 105-111, 2001 
16. Saljo A, Bao F, Jingshan S, Hamberger A, Hansson HA, Haglid KG: Exposure to short-lasting impulse noise causes neuronal c-Jun expression and induction of apoptosis in the adult rat brain. J Neurotrauma 19: 985-991, 2002

17. Saljo A, Bao F, Shi J, Hamberger A, Hansson HA, Haglid KG: Expression of c-Fos and c-Myc and deposition of beta-APP in neurons in the adult rat brain as a result of exposure to shortlasting impulse noise. J Neurotrauma 19: 379-385, 2002

18. Saljo A, Huang YL, Hansson HA: Impulse noise transiently increased the permeability of nerve and glial cell membranes, an effect accentuated by a recent brain injury. J Neurotrauma 20 : 787-794, 2003
19. Serot JM, Christmann D, Dubost T, Béne MC, Faure GC: CSF folate levels are decreased in late onset AD patients. J Neural Trans 108: 93-99, 2001

20. Serot JM, Foliguet B, Bene MC, Faure GC: Choroid plexus and ageing in rats: A morphometric and ultrastructural study. Eur $J$ Neurosci 14: 794-798, 2001

21. Smith AL: Pathogenesis of Haemophilus influenzae meningitis. Pediatr Infect Disease J 6: 733-786, 1987 